\title{
CUSTOMER SATISFACTION SURVEY OF URBAN PUBLIC TRANSPORT
}

\author{
Zbigniew ŻEBRUCKI ${ }^{1 *}$, Mariusz KRUCZEK ${ }^{2}$, Ewelina NIESZPOREK ${ }^{3}$ \\ ${ }^{1}$ Silesian University of Technology, Faculty of Organization and Management; zzebrucki@polsl.pl, \\ ORCID: 0000-0002-6426-2814 \\ ${ }^{2}$ Central Mining Institute; mkruczek@gig.eu, ORCID: 0000-0002-5052-3729 \\ ${ }^{3}$ Silesian University of Technology; ewelina.nieszporek@gmail.com \\ * Correspondence authors
}

Purpose: The main aim of the article is identification of passengers' preferences and satisfaction with public transport services as the basis for evaluating the quality of urban public transport services and it's improvement.

Design/methodology/approach: The research included a satisfaction survey of urban passenger transport customers in the city of Żory, where free public transport operates. The literature review provided an opportunity to identify the factors to be assessed in the survey. Findings: The survey has shown that respondents indicate the frequency of buses, punctuality, the technical condition of the means of transport, the number of seats available on the bus during peak hours and the efficiency of air conditioning and heating as the most important improvements in the quality in organization and realization of public passenger transport. These results are the basis for action by the transport provider.

Research limitations/implications: The survey concerns only the city of Żory public passengers transport, while the proposed research approach can be used in research for other cities.

Practical implications: Adaptation of the transport offer to the passengers requirements in order to encourage them to use public transport more often. This solution will increase the competitiveness of this form of transport in relation to individual transport modes.

Social implications: The quality of passenger transport services in the city plays a key role in shaping the quality of inhabitants life. The competitiveness of this form of transport also influences the environmental aspect - among others, the reduction of low emissions. Nevertheless, in order to ensure the use of this form of transport, it is necessary to continuously improve the offer and quality of service provision.

Originality/value: The presented research is important in the activities of urban passenger transport operators as it provides information on the importance of factors influencing the growth of interest in this type of services, and therefore is important in building a customer service strategy.

Keywords: city logistics, customer satisfaction, public transport.

Category of the paper: technical paper, case study. 


\section{Introduction}

The functioning of people in cities requires movement, which is driven by the need to satisfy various needs. The needs may involve commuting to work, school, cultural and religious centres or resting places. There has been a significant increase in motorisation in Poland in the recent years, accompanied by a decrease in the number of passengers transported by public transport. Because of the increased accessibility to passenger cars, more and more people choose individual transport because of the independence and comfort of travelling. Due to limited road capacity in cities, the issue of transport congestion is growing, which leads to a number of inconveniences related to it. Present-day cities often experience problems such as urban congestion, lack of parking spaces and congestion in the road transport infrastructure. The city authorities have an urgent task to coordinate the city's transport system in such a way as to ensure that its inhabitants are provided with spatial accessibility to places and destinations that are related to meeting their needs. This task seeks to limit congestion in the city. There are many methods and tools to address this issue, but the most vital one is to shape the communication behaviour of the city's inhabitants, which should be focused on increasing the use of public transport potential in passenger transport services. For the inhabitants to be persuaded to use public transport, it is necessary, among other things, to ensure adequate quality of transport and affordable prices. Free public transport, which has been successfully implemented in many cities in Poland, is becoming more and more popular. The free public transport may be offered to all inhabitants and visitors or to specific groups of inhabitants, e.g. students. The introduction of such a solution promotes more frequent use of public transport by passengers and proves to be an answer to the transport problems of the cities. The aim of the article is to present the results of the survey concerning the satisfaction of urban passenger transport customers. The survey was conducted in the city of Żory, where free public transport operates.

\section{The transport needs of the inhabitants of the city}

The transport need is secondary, because it is dependent on primary needs. With regard to public transport, there is a transport need, which can be understood as the need to move from the starting point to the final destination at a specific moment. The overall transport needs of the inhabitants of a given city consist of the individual needs of each individual (Szymczak, 2008). The sources of transport needs can be found in every sphere of human life, but they mostly result from productive and social activities. The needs of the city's inhabitants may be related to work, science and development, cultural needs, or the willingness to maintain social relationships, shopping and leisure. They may also have their origin in the need to benefit from 
health care, to settle matters in the city hall and to use various services provided within the city, as well as for purposes related to the human religious sphere. All of these factors lead to the need to change the place in space, i.e. the need to move. It is manifested in the form of transport executed by various modes of transport (e.g. road, sea, rail and air transport). J. Szołtysek (2011, p. 14) states that all human activity is associated with movement (locomotion). Transport needs that are related to the non-economic sphere of social life are most often the result of (Burnewicz, Grzywacz, 1989):

- locating cultural, scientific and educational facilities in space,

- the living standards of the city's inhabitants,

- using their leisure time,

- life and health saving initiatives of the inhabitants,

- the need to participate in social life,

- the functioning of the public administration,

- national defence and internal security.

The transport need has three dimensions. The first is the quantitative dimension, which indicates the number and length of journeys, then the spatial dimension, which indicates the movement of inhabitants. The last one is the time dimension, which indicates the time of the journey, the date of the journey, as well as time schedules (Szymczak, 2008). The transport need may be focused on a limited area (movements within urbanised areas) or distributed over an unlimited area (movements outside the borders and between remote urbanised centres) (Rydzkowski, Wojewódzka-Król, 2007). Among its features the following can also be distinguished: massive use, diversity, cyclicality of occurrence (transport peaks) or imbalance in time and space. The development of transport needs determining the number of journeys made and the distance covered depends on a number of factors, which may include (Glugiewicz, 1991):

- the population of a given city and its spatial area - its increase causes an increase in the number of potential journeys of the inhabitants,

- the spatial layout of a given city - the more irregular (longitudinal) it is, the longer the average travel distances are covered,

- spatial and functional structure of a given city - the location of places of living and places related to other functions (e.g. workplaces or study) in space determines the number of potential journeys and their average length,

- demographic and social structure of the city's inhabitants, their level of activity and income,

- the amount of leisure time of the inhabitants of a given city.

Transport needs can be classified based on various criteria, such as the type of primary need, where the needs for school, work, social or cultural life of the inhabitants are distinguished. The needs may be either compulsory, i.e. they must be met within well-defined deadlines and 
relations (e.g. commuting to work/school) or non-compulsory, which do not have well-defined deadlines and/or relations (cultural or leisure pursuits). A feature of distinguishing transport needs can also be the spatial relation on which they take place (determined by the direction of travel, names of area units: initial and destination), as well as the expected time of travel (Szymczak, 2008). The classification of reasons for the mobility of people in cities is presented in Figure 1.

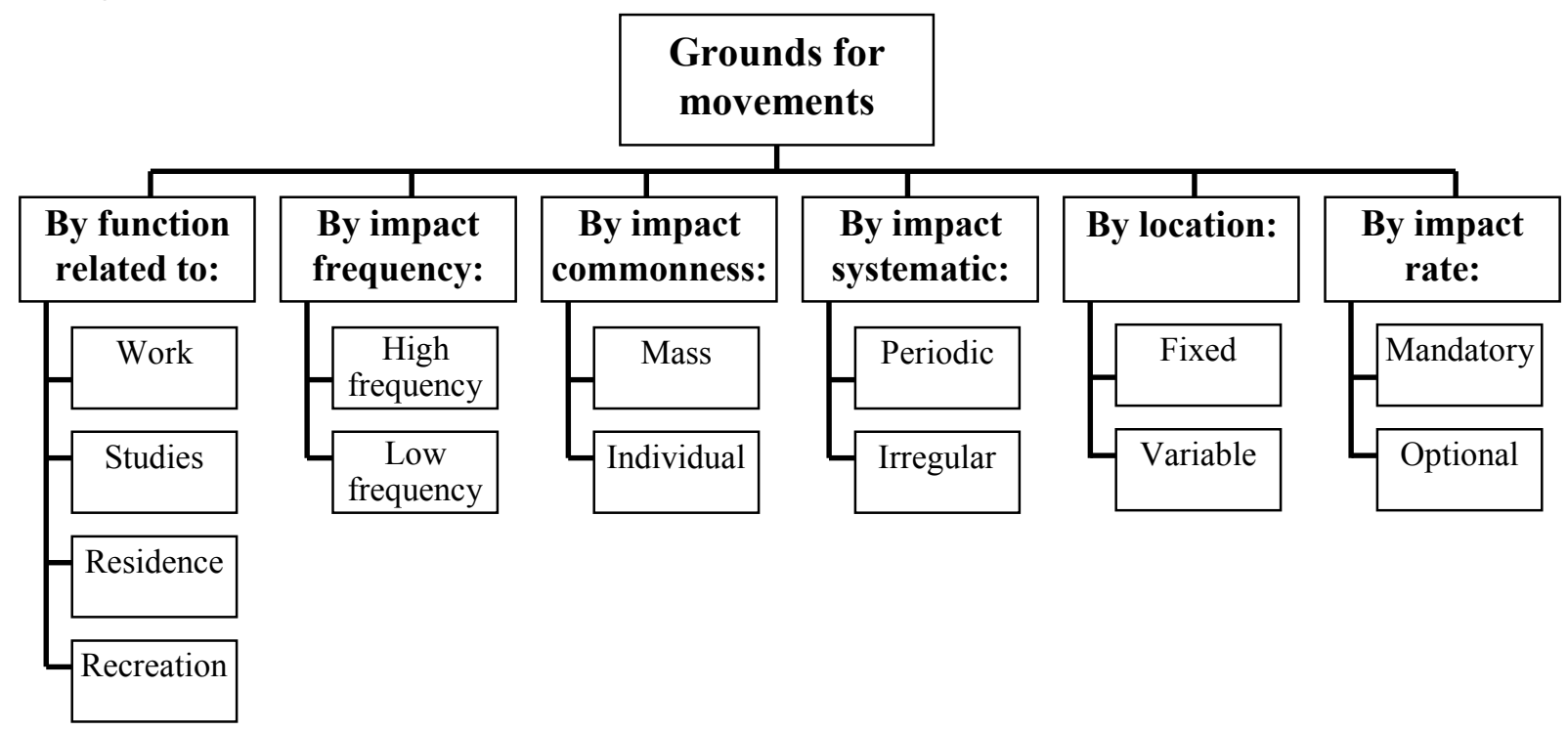

Figure 1. Classification of reasons for urban passenger mobility. Adapted from: Roszko K., Warunki komunikacyjne jako czynnik ksztattujący ruchliwość mieszkańców [Transport conditions as a factor shaping the mobility of inhabitants], Instytut Kształtowania Środowiska, Katowice, 1971, s. 23.

The transport needs of inhabitants generate demand for transport. This demand is known as potential demand because not every need is met by transport. It has the chance to turn into an effective demand by creating the right conditions in the form of an attractive transport offer. These include: fare offer, timetable, rolling stock, information and safety. The transport offer should take into account all the preferences of potential passengers in terms of service level so that they are willing to consider it (Hebel, 2007).

The movement of people in cities is a reflection of the fulfilment of the mobility of its inhabitants. A journey may consist of one or several individual movements that meet the completeness requirement, i.e. lead to a planned accessibility to the destination. Urban mobility can be undertaken on foot, by individual (private) or public transport (Szołtysek, 2016). The share of public transport services in total transport is unequal. It depends on the following factors (Szołtysek, 2009):

- the degree of wealth of society,

- accessible transport infrastructure (linear and spot),

- the existing system of incentives,

- spatial conditions of using public transport. 


\section{The concept of quality within urban public transport}

The basis for assessing the quality of urban public transport services is to identify the passengers' preferences and satisfaction with urban transport services. Understanding customers' expectations makes it possible to offer them the level of service they expect. The quality of public passenger transport services according to the Polish Standard (PN-EN-13816:2002(U)) is defined as a set of quality criteria and measures for which the transport service provider is responsible (Ciastoń-Ciulkin, 2015). The quality can be examined from the point of view of the passenger and the municipal authorities representing them (expected and perceived quality) and the carrier providing the service (target and delivered quality). The representation of these two views on quality is shown in the so-called quality loop, shown in Figure 2.

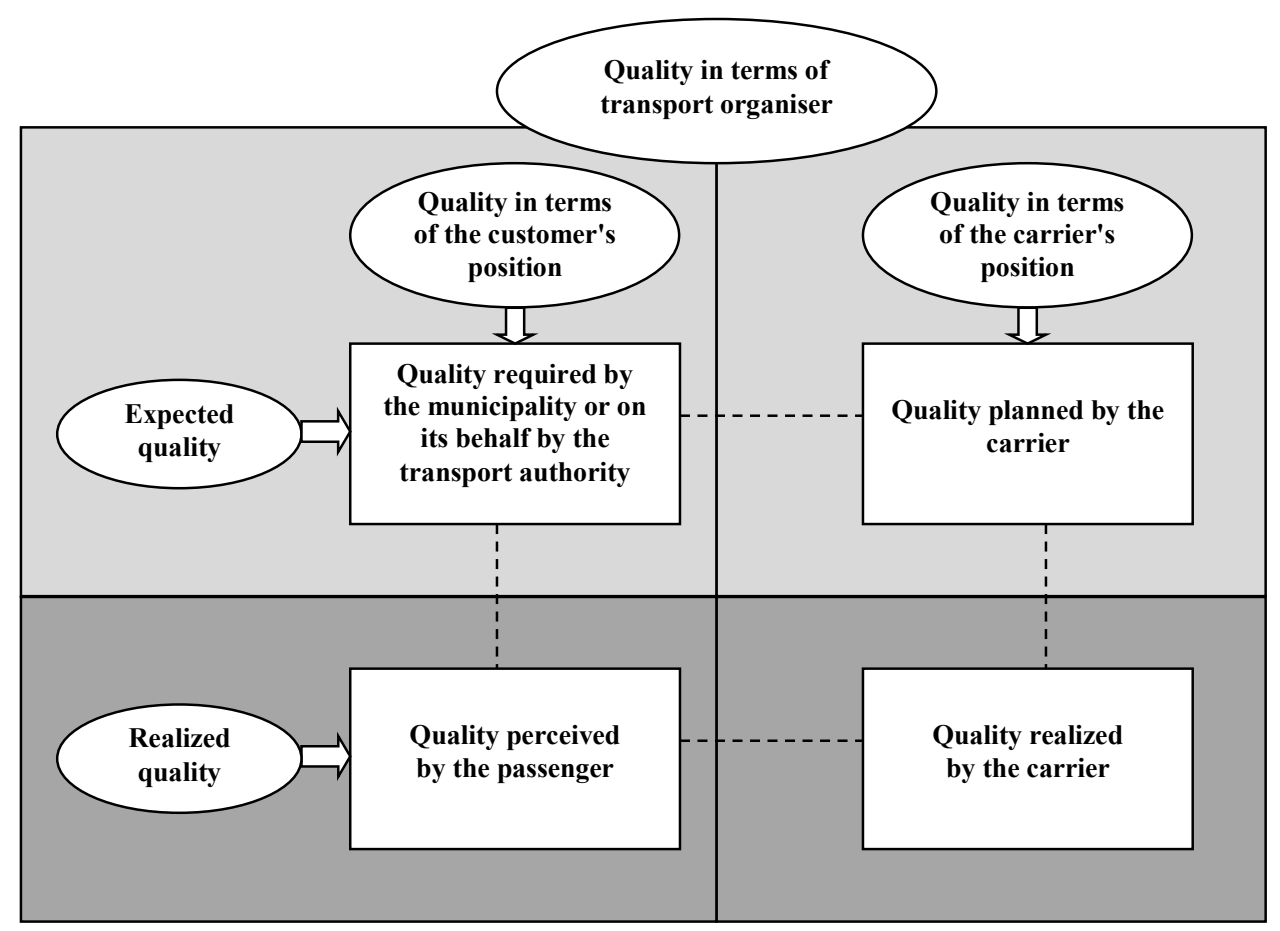

Figure 2. Classification of reasons for urban passenger mobility. Adapted from: Starowicz W., Jakość przewozów w miejskim transporcie zbiorowym [The quality of transport in urban collective transport], Wydawnictwo Politechniki Krakowskiej, Kraków, 2007, s. 27.

Differences may appear between the individual links in the loop, the most significant of which is the difference between expected and perceived quality. This gap provides a lot of information that is relevant for making decisions related to the improvement and further development of the current transport system in the city.

The target quality level of the public transport operator is set on the basis of quality standards. These standards, compared to the results obtained, determine the quality delivered. The degree of expected and perceived quality is determined by means of marketing studies which reflect the preferences and satisfaction of passengers with public transport services. 
The procedure for the process of establishing a quality profile for passengers using urban transport is as follows (Ciaston-Ciulkin, 2015):

- the assignment of the expected quality features of the expected ratings on a predetermined scale, the assigned ratings show the level of quality that is preferred by public transport customers,

- the assignment of individual quality features perceived according to the same scale, the ratings assigned express satisfaction and the extent to which these features are met,

- identification of a quality gap that indicates differences between preferences and customer satisfaction.

For Polish conditions, a list of passenger service standards has been created, which corresponds to the conditions that are expected from public transport in urbanised areas in the European Union countries (Figure 3).

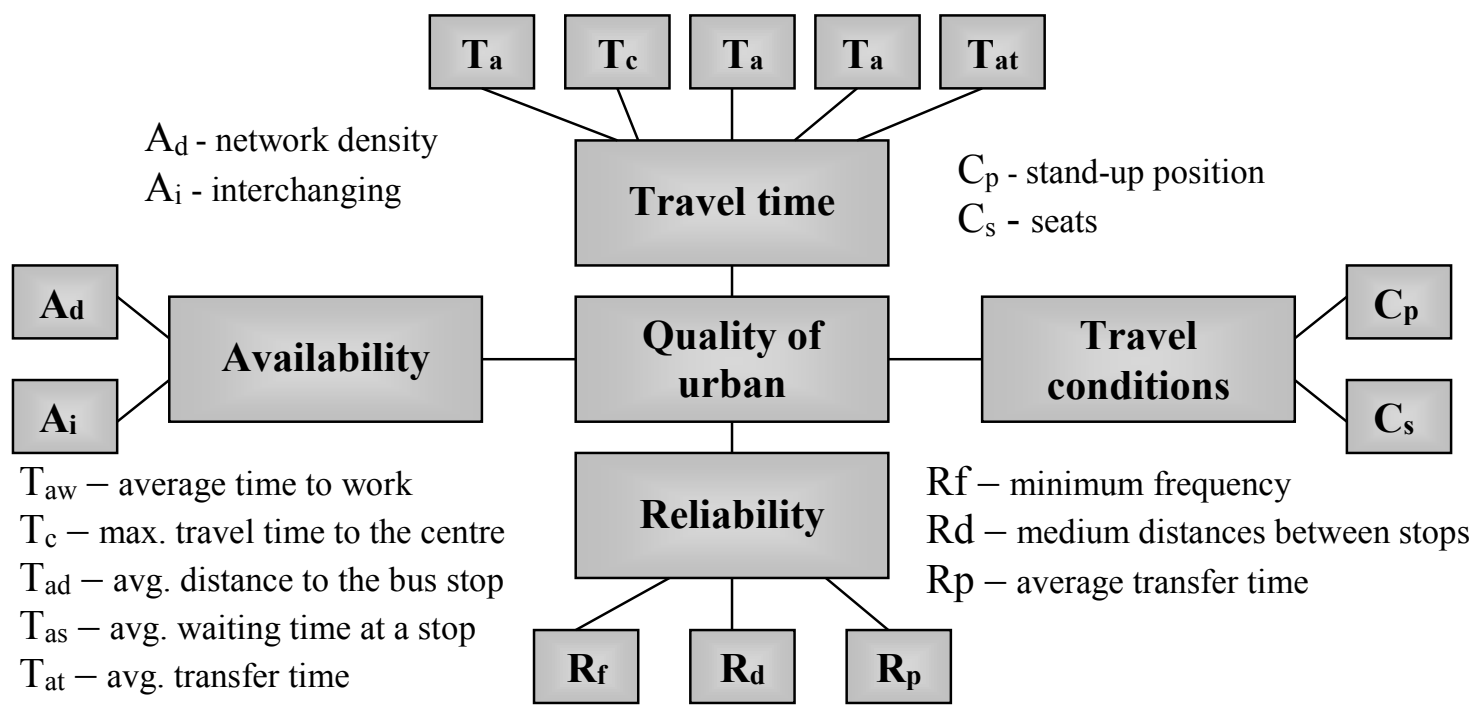

Figure 3. Classification of reasons for urban passenger mobility. Adapted from: Starowicz W., Jakość przewozów w miejskim transporcie zbiorowym [The quality of transport in urban collective transport], Wydawnictwo Politechniki Krakowskiej, Kraków, 2007, s.40.

The quality of transport should be evaluated in three areas (Starowicz, 2007): quality carriers - such as bus stop and shelter infrastructure, stations, vehicles; travel components in order to influence those elements that need to be improved first; market segments such as passengers with decreasing mobility, allowing them to start using public transport again. Measurements of the quality of transport services by the passenger are mainly based on identifying their expectations (preferences) and, afterwards, feelings (satisfaction). While surveying, the majority of cases are quantitative and statistical in nature. In passenger satisfaction survey, an essential aspect is to control the quality of urban transport services. The basic criterion for evaluating the quality gap that occurs from the passenger's point of view are the so-called transport postulates, which can be defined as demands for meeting the transport needs of public transport passengers. Referring to urban public transport services, the concept of quality can be defined as the degree of satisfaction of the transport needs of 
passengers, which is measured by a set of postulates. Table 1 shows a list of 10 postulates, which are used to examine the quality of public transport services in Poland.

\section{Table 1.}

The transport postulates

\begin{tabular}{|c|c|c|c|}
\hline No & Postulate & Meaning of the postulate & $\begin{array}{l}\text { The way to determine the fulfilment } \\
\text { of the postulate }\end{array}$ \\
\hline 1. & accessibility & $\begin{array}{l}\text { distance from the stop (spatial or time- } \\
\text { based) }\end{array}$ & $\begin{array}{l}\text { maximum distances for effortless access by } \\
\text { pedestrians }\end{array}$ \\
\hline 2. & frequency & departure intervals & $\begin{array}{l}\text { acceptable intervals between successive } \\
\text { transport vehicles in certain relations and times }\end{array}$ \\
\hline 3. & punctuality & $\begin{array}{l}\text { compliance with the timetable for } \\
\text { departures }\end{array}$ & deviation tolerance \\
\hline 4. & safety & $\begin{array}{l}\text { personal safety of travellers at stops } \\
\text { and in transport vehicles }\end{array}$ & desirable feeling of safety \\
\hline 5. & directness & direct connections without stopovers & $\begin{array}{l}\text { desirable direct connections taking into account } \\
\text { different time of day }\end{array}$ \\
\hline 6. & reliability & arrival at destination on time & deviation tolerance \\
\hline 7. & speed & $\begin{array}{l}\text { travelling time including stops on the } \\
\text { route }\end{array}$ & $\begin{array}{l}\text { attractive or acceptable journey time in relation } \\
\text { to different distances }\end{array}$ \\
\hline 8. & cost & one-off or periodic fees & $\begin{array}{l}\text { desirable tariff system, ticket distribution and } \\
\text { validation system, attractive level of one-off and } \\
\text { periodic fees under a specific tariff system }\end{array}$ \\
\hline 9. & comfort & $\begin{array}{l}\text { a set of elements determining the } \\
\text { conditions of waiting at a stop and } \\
\text { staying in a transport vehicle }\end{array}$ & $\begin{array}{l}\text { desirable waiting conditions for the bus, } \\
\text { minimum standard of the stops, desired } \\
\text { travelling conditions, minimum travelling } \\
\text { standard }\end{array}$ \\
\hline 10. & information & $\begin{array}{l}\text { way of communicating information } \\
\text { about the transport offer and changes } \\
\text { in the offer }\end{array}$ & $\begin{array}{l}\text { desirable method and type of information access, } \\
\text { minimum standard depending on the type of } \\
\text { information accessed }\end{array}$ \\
\hline
\end{tabular}

Adapted from: Starowicz W., Jakość przewozów w miejskim transporcie zbiorowym [The quality of transport in urban collective transport], Wydawnictwo Politechniki Krakowskiej, Kraków, 2007, p. 43.

\section{Customer satisfaction survey of urban public transport in Żory}

The survey was conducted in the period from 7 September to 17 October 2017. The survey titled "Survey of passenger satisfaction with the free-fare operation of urban public transport in Żory" was an Internet survey [CAWI]. As a courtesy of the Żory Town Hall, the survey has been published on the website www.tuzory.pl. It was anonymous and addressed to all users of free-fare public transport in Żory and all other inhabitants of the city. The organiser of passenger transport in Żory is Międzygminny Związek Komunikacyjny [Inter-Communal Transport Association] with its headquarters in Jastrzębie Zdrój, while the transport operations are carried 
out by V-BUS company with its headquarters in Żory. The free-fare urban public transport has been operating since 1 May 2014, with seven routes serving all districts of the city. Żory is the first larger city in Poland where free-fare transport is available without any restrictions not only for every inhabitant, but also for all visitors. The survey was attended by 402 people, so it is a large sample. The survey questionnaire consisted of 20 questions, which included 18 closedended questions and 2 open-ended questions. The entire survey can be divided into three main parts: questions to identify the structure of the sample; evaluation of individual transport postulates with their specification; expectations of inhabitants regarding free-fare public transport (these can serve to improve its functioning).

The survey was conducted by 248 women and 154 men, the age structure was as follows: 126 respondents aged 27-39; 102 respondents aged 40-65; 92 respondents aged 19-26 and 14 respondents above 65 . More than half of the respondents $(56 \%)$ declared their status as employed; pupils/students (not employed) accounted for $20 \%$ of the respondents, pensioners $10 \%$, while the rest were working pupils/students (8\%), unemployed (4\%) and working pensioners $(2 \%)$. A total of $58 \%$ of the respondents ( 234 people) declared that they do not own or use a car, while the remaining 168 people stated that they use a car to meet their transport needs.

Among the factors why the respondents prefer to travel by public transport rather than by car, more than $60 \%$ indicated that it is not possible to travel by car (no car/driving license/other). The reason why about $50 \%$ of respondents choose public transport is because of lower travel costs compared to driving a car. Traffic congestion, difficulties with parking at the destination, time saving or other reasons were similar (14-17\% of respondents). The least important reason was given for poor condition of road infrastructure (only 2.7\%), which may indicate that the condition of road infrastructure in Żory is satisfactory for the inhabitants and causes no difficulties in travelling (Figure 4).

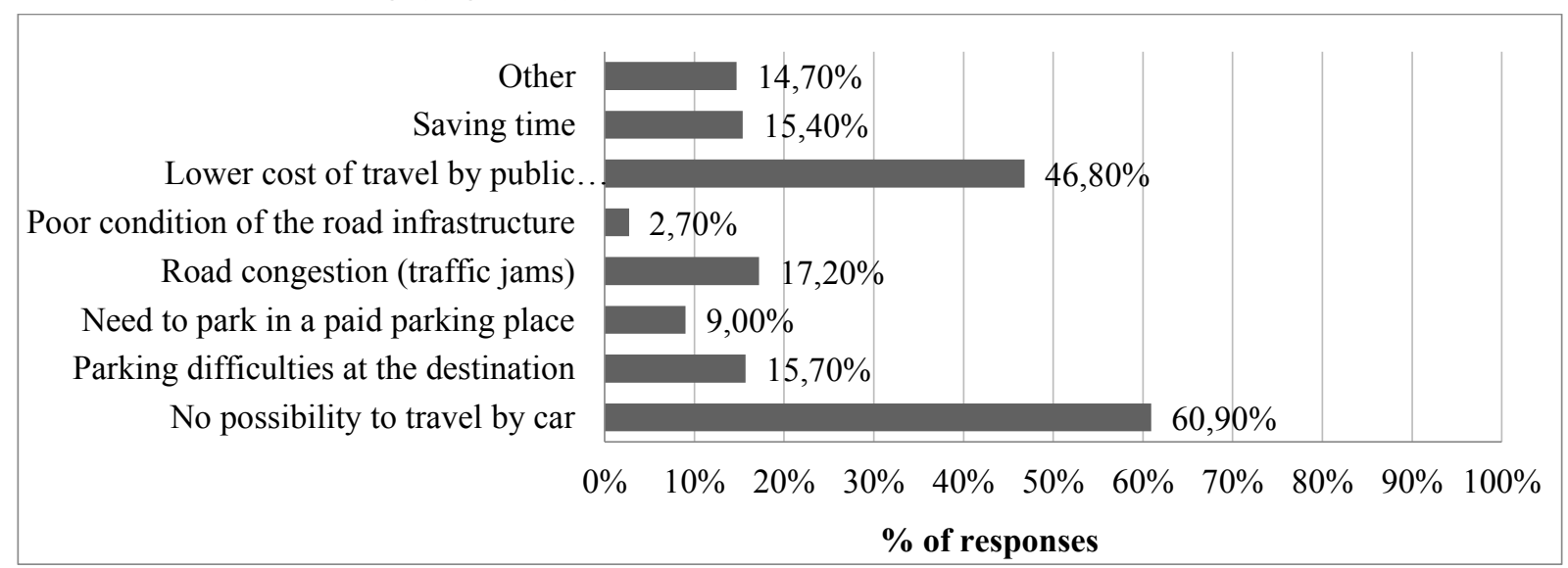

Figure 4. The reasons for choosing public transport. Adapted from: own work.

Among the reasons for using public transport the respondents most often mentioned social meetings (207 people) and personal matters (206 people). Every second respondent commutes to social meetings by public transport, which may be related to the desire to drink alcohol at the 
destination (Figure 5). About 40\% of the respondents use public transport for commuting to work and shopping. However, only $25 \%$ of the respondents indicated that they commute to school/university, which may be due to the fact that pupils and students account for $1 / 4$ of all respondents.

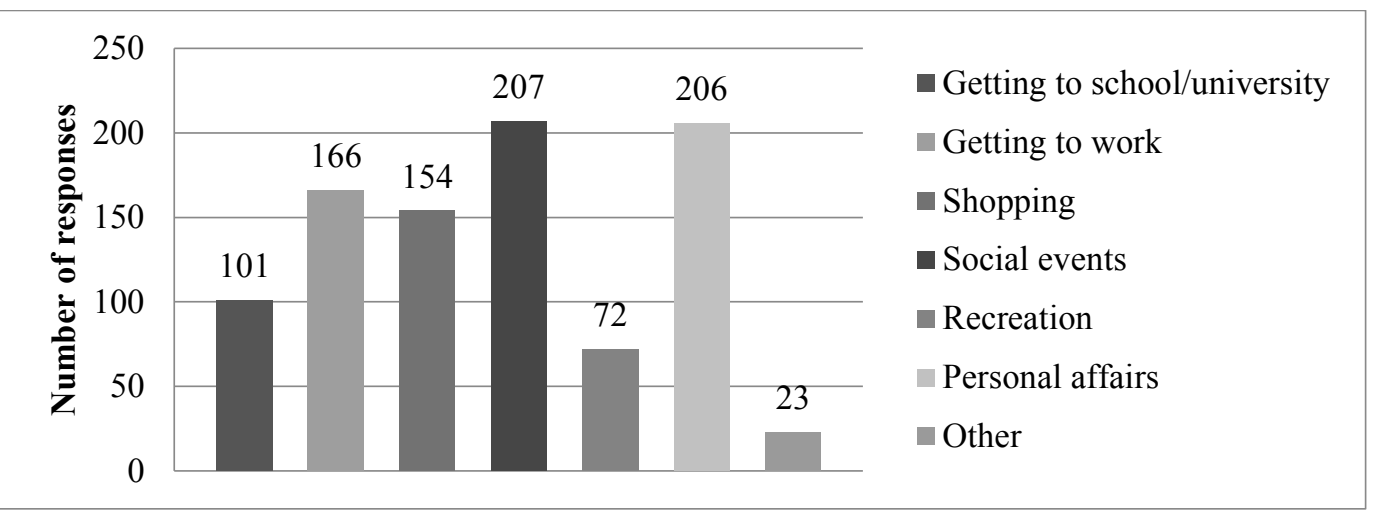

Figure 5. The reasons for travelling by public transport. Adapted from: own work.

More than two hundred respondents indicated the frequency of buses and the availability of the transport network (distance from the stop), when asked what has the greatest impact on the quality of public transport travel. Then, the punctuality and cost of journey were indicated by slightly more than 140 people. More than one hundred answers were also given to the directness of the journey. What seemed to be the least significant for the respondents was the number of free seats on the bus outside the rush hour and the condition of the stops - each of them received less than twenty answers. Respondents also rarely chose the stopover waiting time or safety (25 - 26 people) (Figure 6).

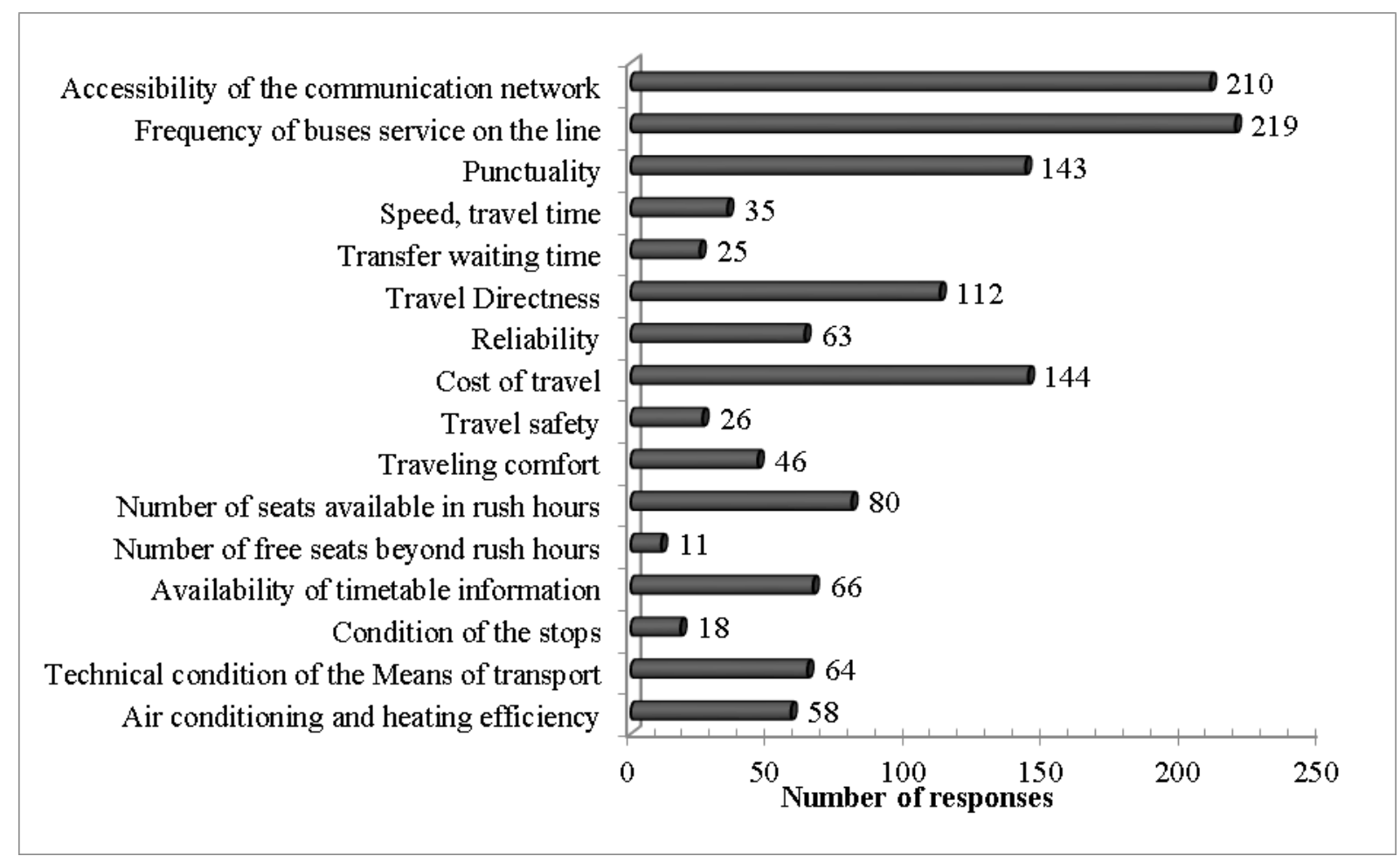

Figure 6. Postulates having the greatest impact on the quality of public transport services according to the respondents. Adapted from: own work. 
In the next question, the respondents were asked to evaluate the importance of individual transport postulates on a 5-point scale. More than half of the respondents evaluated the following postulates as very crucial: punctuality, frequency, reliability, safety of the journey, technical condition of the means of transport, cost of the journey and availability of timetable information. The highest proportion of "totally unimportant", "minor" and "medium" ratings in comparison to "important" and "very important" ratings were given to the following postulates: the condition of stops and the number of free seats outside the rush hour. The "important" ratings outweighed the other ratings by the following postulates: speed, travel time, comfort of travel and stopover waiting time (Figure 7).

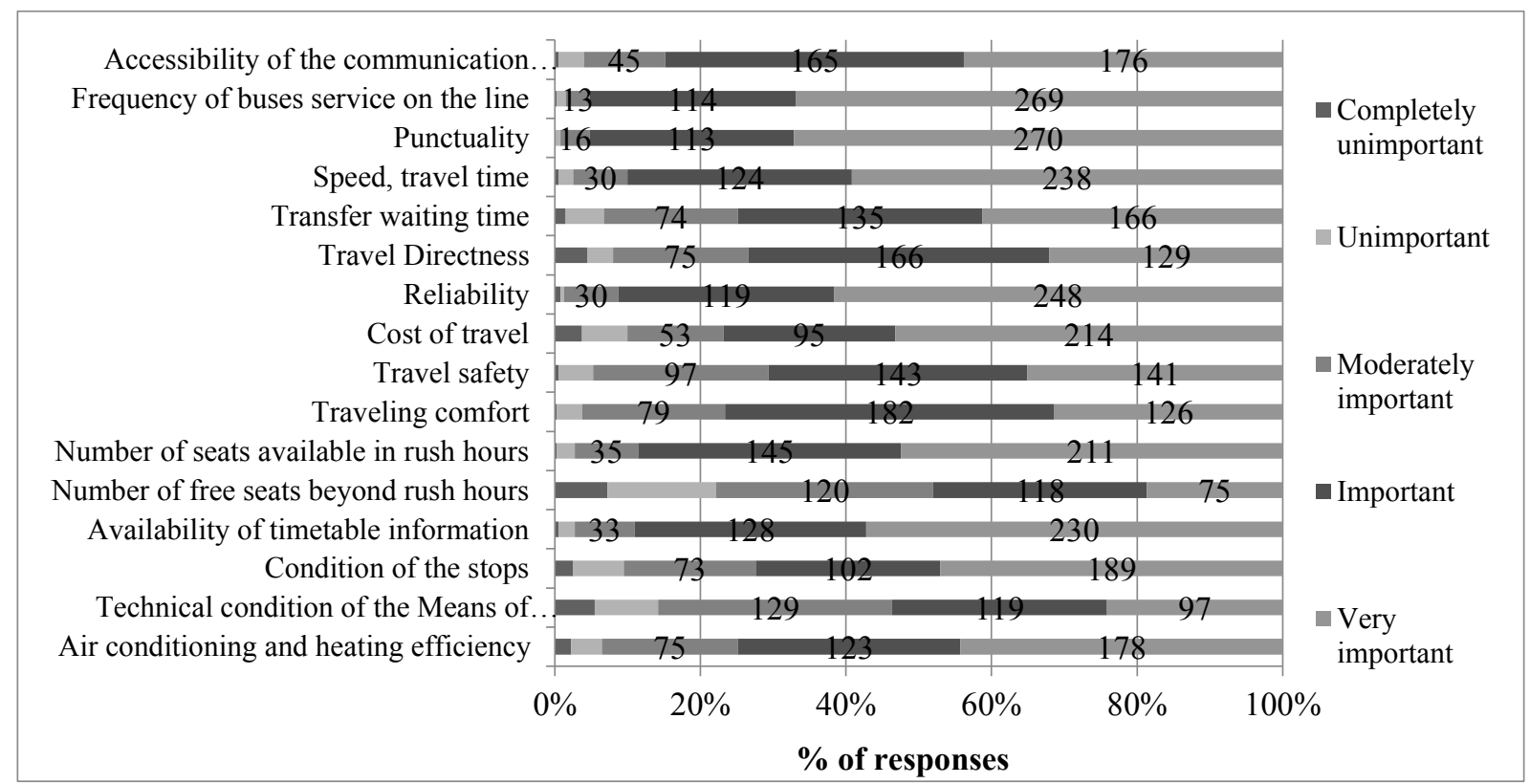

Figure 7. Evaluation of the significance of particular transport postulates according to the respondents. Adapted from: own work.

The technical condition of the free-fare public transport fleet [BKM] was evaluated by the respondents as 3.4 on a 5-point scale, with 1 being the lowest and 5 the highest. When asked whether the free-fare public transport fleet is sufficiently adjusted to transport the disabled, the elderly, with pushchairs and pregnant women, the majority of people — as many as $39 \%$ expressed a negative opinion on the subject. The lack of opinion was declared by $32 \%$ of the respondents and only $29 \%$ of the respondents stated that the BKM fleet is adjusted to the needs of the disabled and others mentioned above (Figure 8).

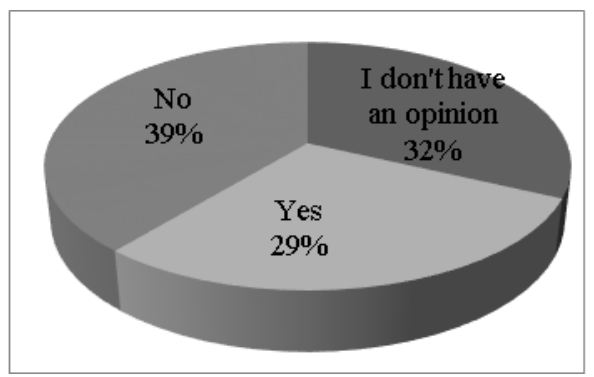

Figure 8. The current state of adaptation of the free-fare public transport fleet to transport the disabled, the elderly, with pushchairs and pregnant women according to the respondents. Adapted from: own work. 
The information about the timetable is most often taken from the website $(76 \%$ of respondents). Only slightly fewer of them (61\% of those surveyed) use timetables posted at the bus stops. The mobile application is not very popular among passengers, only $30 \%$ of respondents use it (Figure 9). Almost three times more respondents choose a website compared to the mobile application.

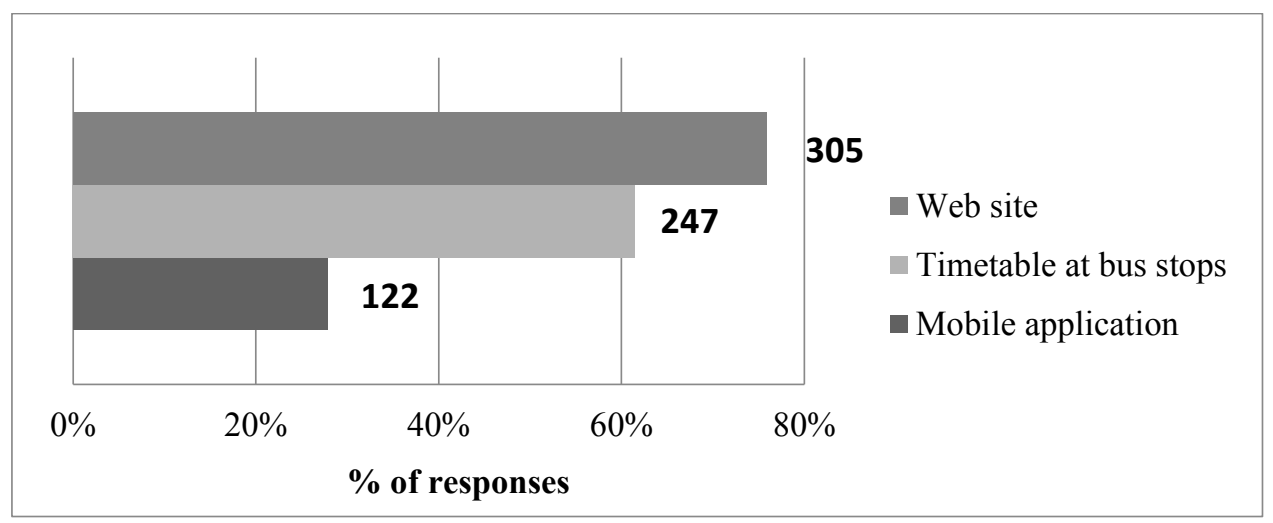

Figure 9. The sources from which respondents get information on BKM bus timetables. Adapted from: own work.

About $45 \%$ of respondents believe that the introduction of free-fare urban public transport in Żory has led to a decrease in car traffic in the city and at the same time has contributed to a decrease in air pollution. Only $30 \%$ of the respondents expressed the opposite opinion, and $26 \%$ of the respondents expressed no opinion on the subject. According to the respondents, the expected activities of the BKM in Żory are mainly to increase the capacity of buses and to increase the frequency of operation during the rush hours, as indicated by more than half of the respondents. About $30-40 \%$ of the respondents expect an improvement in punctuality, an increase in the frequency of service beyond the rush hours, the purchase of modern buses and the introduction of new bus routes (Figure 10). The least desirable actions, indicated by less than $10 \%$ of the respondents, are to improve the condition of bus shelters, improve the legibility of timetables and others, which include: greater care for the technical condition of buses and maintaining tidiness in the passenger space, increasing space for pushchairs and wheelchairs, improving the propriety of drivers, improving air conditioning and heating in winter time, improving reliability, adjusting timetables to schools' schedules, synchronising timetables with intercity carriers.

The overall satisfaction of passengers with the operation of free-fare urban public transport in Żory is 3.8 on a 5-point scale. The highest number of respondents rated the BKM as 4.0 (159 people), while the lowest number of respondents rated 1.0 (15 people). The respondents evaluated the fulfilment of particular transport postulates by each of the BKM bus routes operating in the city (seven routes). The descriptive results of the fulfilment of individual postulates on all routes are presented in Table 2. 


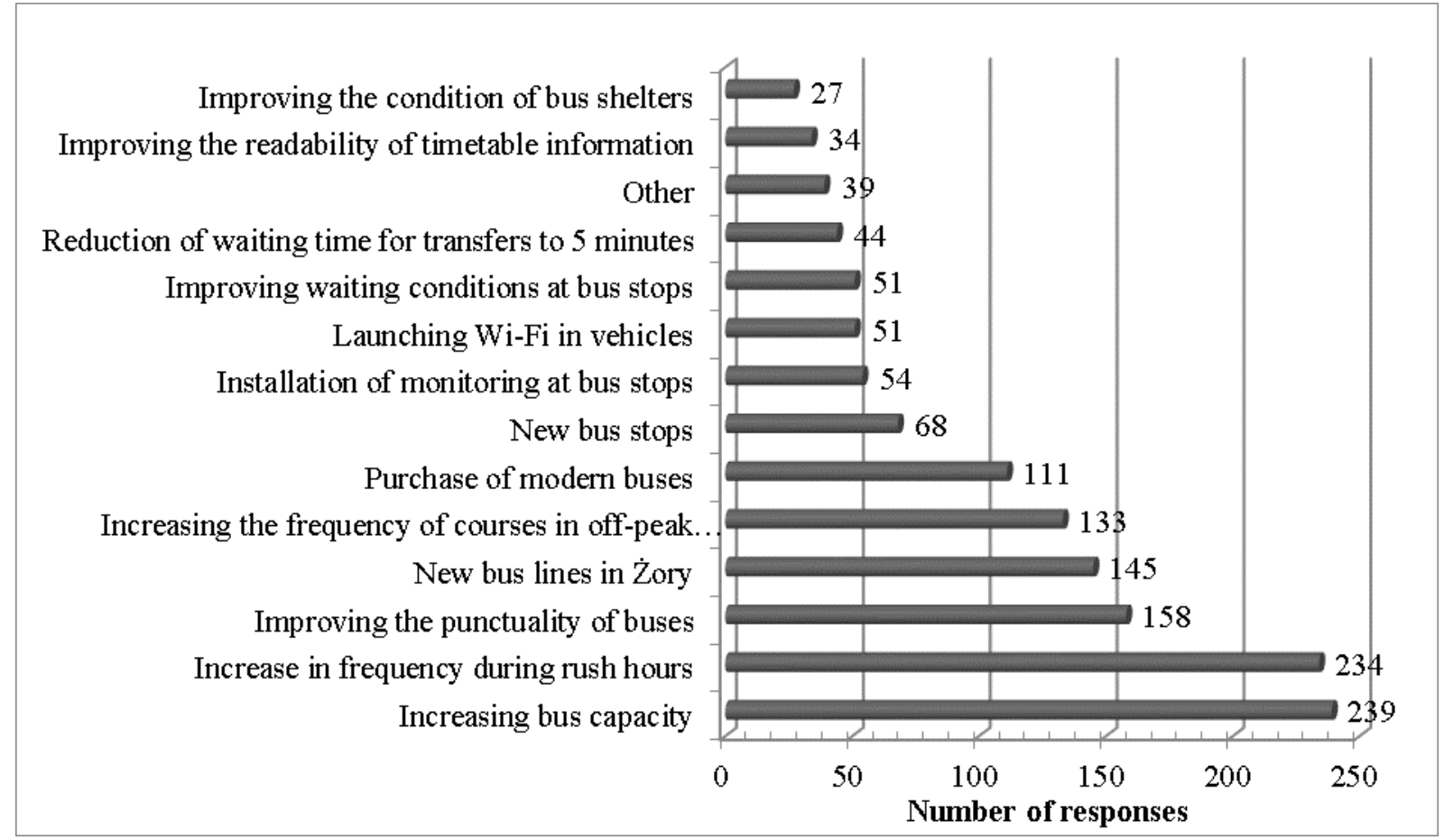

Figure 10. Expected activities of the BKM in Żory according to the respondents. Adapted from: own work.

Among all the transport postulates, whose importance and degree of fulfilment by KBM were evaluated by means of surveys, the respondents first indicated the following as requiring improvement: bus frequency; punctuality; technical condition of transport vehicles; number of available seats in the bus during the rush hours and efficiency of air conditioning and heating.

Table 2.

Execution of transport postulates on particular BKM routes

\begin{tabular}{|c|c|c|c|c|c|c|c|}
\hline Transport request & $\begin{array}{l}\text { Line } \\
\text { no } 01\end{array}$ & $\begin{array}{l}\text { Line } \\
\text { no } 02\end{array}$ & $\begin{array}{l}\text { Line } \\
\text { no } 03\end{array}$ & $\begin{array}{l}\text { Line } \\
\text { no } 04\end{array}$ & $\begin{array}{l}\text { Line } \\
\text { no } 05\end{array}$ & $\begin{array}{l}\text { Line } \\
\text { no } 06\end{array}$ & $\begin{array}{l}\text { Line } \\
\text { no } 07\end{array}$ \\
\hline Availability of the communication network & $\mathrm{M}$ & $\mathrm{M}$ & $\mathrm{M}$ & $\mathrm{M}$ & $\mathrm{M}$ & $\mathrm{M}$ & $\mathrm{M}$ \\
\hline Frequency of buses services & $\mathrm{M}$ & $\mathrm{M}$ & IS & IS & IS & IS & IS \\
\hline Punctuality & IS & IS & IS & IS & $\mathrm{M}$ & M & $\mathrm{M}$ \\
\hline Travel safety & $\mathrm{M}$ & $\mathrm{M}$ & $\mathrm{M}$ & $\mathrm{M}$ & $\mathrm{M}$ & $\mathrm{M}$ & $\mathrm{M}$ \\
\hline Directness of travel & $\mathrm{M}$ & $\mathrm{M}$ & $\mathrm{M}$ & $\mathrm{M}$ & $\mathrm{M}$ & $\mathrm{M}$ & $\mathrm{M}$ \\
\hline Waiting time for transfers & $\mathrm{I}$ & $\mathrm{I}$ & IS & IL & IL & IL & IS \\
\hline Reliability & $\mathrm{M}$ & $\mathrm{M}$ & $\mathrm{M}$ & IS & $\mathrm{M}$ & $\mathrm{M}$ & $\mathrm{M}$ \\
\hline Traveling comfort & IL & IL & IL & IL & IL & IL & IL \\
\hline Speed, travel time & $\mathrm{I}$ & $\mathrm{I}$ & $\mathrm{I}$ & $\mathrm{I}$ & $\mathrm{I}$ & $\mathrm{I}$ & $\mathrm{I}$ \\
\hline Availability of timetable information & $\mathrm{M}$ & $\mathrm{M}$ & $\mathrm{M}$ & $\mathrm{M}$ & $\mathrm{M}$ & $\mathrm{M}$ & $\mathrm{M}$ \\
\hline Condition of stops & I & I & I & I & I & I & I \\
\hline Technical condition of vehicles & $\mathrm{M}$ & $\mathrm{M}$ & IS & IS & IS & IS & $\mathrm{M}$ \\
\hline $\begin{array}{l}\text { Number of seats available on the bus during } \\
\text { rush hours }\end{array}$ & IS & IS & IS & IS & IL & IL & IS \\
\hline $\begin{array}{l}\text { Number of seats available on the bus outside } \\
\text { rush hours }\end{array}$ & IL & IL & I & $\mathrm{I}$ & $\mathrm{I}$ & $\mathrm{I}$ & IL \\
\hline Air conditioning and heating efficiency & IS & IS & IS & IS & IL & IS & IS \\
\hline
\end{tabular}

Key: N - Factors not significant (possibility of transferring funds to other areas), U - Factors to be maintained, PD - Factors to be improved in the last order (in the long term), PK- Factors to be improved in the first place (in the short term).

Adapted from: own work. 
The identified operational issues of the BKM have been assigned a significance on a 5-point scale, according to the opinion given by the passengers in the survey. Then a correlation analysis (based on VALSAT analysis) was made for each issue in turn with suggested improvements in BKM operation (Table 3). To this end, the following scale was adopted: 1 - weak correlation, 5 - medium correlation, 10 - strong correlation.

Table 3.

The correlation analysis of the suggested improvements and the identified issues

\begin{tabular}{|c|c|c|c|c|c|c|c|c|c|c|c|c|c|c|}
\hline & & 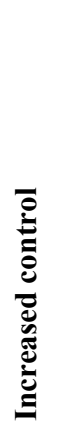 & 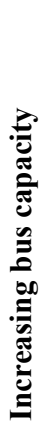 & 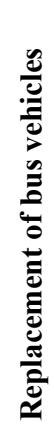 & 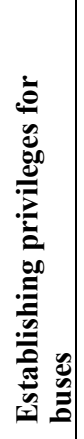 & 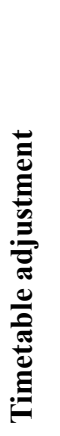 & 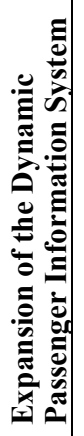 & 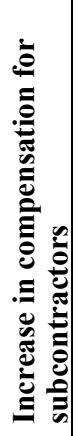 & 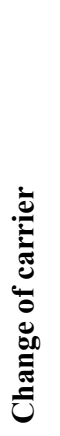 & 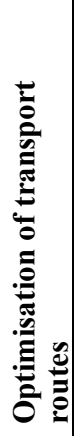 & 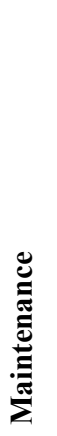 & 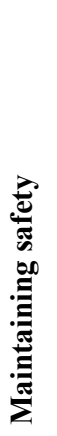 & 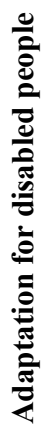 & 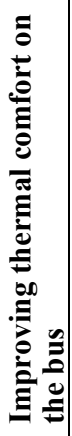 \\
\hline $\begin{array}{l}\text { The main causes of } \\
\text { problems in the } \\
\text { functioning of the BKM } \\
\text { (free public transport) }\end{array}$ & $\sum^{\frac{1}{200}}$ & \multicolumn{13}{|c|}{ Correlation analysis 10 - strong; 5 - medium; 1 - weak) } \\
\hline Low bus frequency & 4,60 & 0 & 0 & 0 & 0 & 10 & 0 & 0 & 0 & 5 & 0 & 0 & 0 & 0 \\
\hline Lack of punctuality & 4,62 & 5 & 0 & 1 & 10 & 1 & 5 & 5 & 1 & 1 & 0 & 0 & 0 & 0 \\
\hline $\begin{array}{l}\text { Long waiting times for } \\
\text { transfers }\end{array}$ & 3,93 & 0 & 0 & 0 & 0 & 10 & 5 & 0 & 0 & 5 & 0 & 0 & 0 & 0 \\
\hline Low reliability & 4,51 & 5 & 0 & 5 & 5 & 1 & 1 & 5 & 1 & 0 & 0 & 0 & 0 & 0 \\
\hline $\begin{array}{l}\text { Bad technical condition of } \\
\text { vehicles }\end{array}$ & 4,43 & 5 & 0 & 10 & 0 & 0 & 0 & 5 & 10 & 0 & 0 & 1 & 0 & 0 \\
\hline $\begin{array}{l}\text { Insufficient seats during } \\
\text { rush hours }\end{array}$ & 4,07 & 1 & 10 & 5 & 0 & 5 & 0 & 0 & 1 & 0 & 0 & 1 & 5 & 0 \\
\hline Low travel comfort & 4,00 & 5 & 10 & 10 & 0 & 5 & 1 & 5 & 0 & 5 & 10 & 5 & 10 & 10 \\
\hline \multirow[t]{3}{*}{$\begin{array}{l}\text { Air conditioning and } \\
\text { heating not working }\end{array}$} & 4,10 & 10 & 0 & 10 & 0 & 0 & 0 & 5 & 10 & 0 & 0 & 0 & 0 & 10 \\
\hline & & \multicolumn{13}{|c|}{ Total weight } \\
\hline & & $\begin{array}{l}\hat{\infty} \\
\hat{n} \\
\tilde{n}\end{array}$ & $\overbrace{\infty}^{\infty}$ & $\begin{array}{l}\tilde{S} \\
\tilde{\Sigma} \\
\tilde{\Sigma}\end{array}$ & $\frac{n}{n}$ & $\begin{array}{l}\stackrel{\infty}{N} \\
\stackrel{m}{m}\end{array}$ & $\underset{\text { in }}{\text { in }}$ & $\begin{array}{l}\text { ભે } \\
\text { ô } \\
\stackrel{0}{0}\end{array}$ & $\begin{array}{l}\tilde{n}^{\prime} \\
\stackrel{\infty}{a}\end{array}$ & $\underset{\hat{~}}{6}$ & $\stackrel{\stackrel{\ominus}{\ominus}}{\stackrel{+}{+}}$ & $\begin{array}{l}\stackrel{\odot}{n} \\
\stackrel{\infty}{\sim}\end{array}$ & శ్ & $\frac{8}{\infty}$ \\
\hline
\end{tabular}

Adapted from: own work.

The sum of the products of weight of each operational issue together with an assessment of its correlation with the individual improvement determines the total weight of the improvement. The highest total weight have been given to the following improvements: increased control (this could be done through e.g. the method of Mystery Shopping with the relevant control cards prepared), replacing the existing bus rolling stock and correcting the timetable (closer alignment with the inhabitants' requirements). These problems should be addressed by the carrier as a priority. 


\section{Conclusions}

The sources of transport needs can be observed in every sphere of human life, however, they mainly result from the productive and social activity of a person. They are divided into compulsory (e.g. commuting to work/school) and non-compulsory (cultural or leisure) needs. These factors cause the need to change place in space, that is, the need to move. It is very crucial in managing the flows of people that they are organised in such a way that the movement of people does not create a barrier limiting the current functioning and development of the city. This is the most essential role of logistics in this regard. It is therefore becoming necessary to divide transport tasks between individual and public transport (and within the collective transport system between the respective means of transport and carriers) in such a way that this division takes into consideration the principles established by the city and is accepted by the inhabitants. The basis for evaluating the quality of public transport services is to identify the preferences and satisfaction of passengers with public transport services. Understanding passengers' expectations provides them with a level of service that they expect. The basic criterion for this evaluation are the so-called transport postulates, that is, the requirements for meeting the transport needs of passengers, which include, for example, punctuality, frequency, safety or travel cost. Due to the fact that the expectations and requirements of passengers are constantly changing, it is recommended to regularly survey the satisfaction and transport needs of public transport users. Adapting the transport offer to passengers' requirements aims to encourage them to use public transport more often, which will increase competition for private transport modes.

\section{References}

1. Burnewicz, J., Grzywacz, W. (1989). Ekonomika transportu. Warszawa: Wydawnictwo Komunikacji i Łączności.

2. Ciastoń-Ciulkin, A. (2015). Jakość usług przewozowych i jej elementy składowe. Transport miejski i regionalny, 1 .

3. Gługiewicz, Z. (ed.) (1991). Transport miejski. Skrypty Uczelniane, 413. Wydawnictwo Akademii Ekonomicznej w Poznaniu.

4. Hebel, K. (2007). Potrzeby przewozowe jako determinanty popytu na usługi transportu miejskiego. Przegląd komunikacyjny, 12.

5. Nieszporek, E. (2018). Analiza procesów logistycznych transportu miejskiego, pasażerskiego $w$ wybranym mieście. Projekt inżynierski napisany pod kierunkiem naukowym Z. Żebruckiego. Zabrze: Politechnika Śląska, Wydział Organizacji i Zarządzania. 
6. Roszko, K. (1971). Warunki komunikacyjne jako czynnik kształtujący ruchliwość mieszkańców. Katowice: Instytut Kształtowania Środowiska.

7. Rydzkowski, W., Wojewódzka-Król, K. (eds.) (2007). Transport. Warszawa: PWN.

8. Starowicz, W. (2007). Jakość przewozów w miejskim transporcie zbiorowym. Kraków: Wydawnictwo Politechniki Krakowskiej.

9. Szołtysek, J. (2009). Logistyczne aspekty zarządzania przepływami osób i ładunków w miastach. Katowice: Wydawnictwo Ekonomiczne.

10. Szołtysek, J. (2011). Kreowanie mobilności mieszkańców miast. Warszawa: Wolters Kluwer.

11. Szołtysek, J. (2016). Logistyka miasta. Warszawa: PWE.

12. Szymczak, M. (2008). Logistyka miejska. Akademia Ekonomiczna w Poznaniu. 